The

Indian

Craze

$\diamond \diamond \diamond$ 
• $\bullet \quad$ objects/histories

Critical Perspectives on Art,

Material Culture, and Representation

A series edited by Nicholas Thomas

Published with the assistance

of the Getty Foundation. 


\section{The \\ Indian \\ Craze}

P R I M I T IVIS M, MODERNISM, AND

TRANSCULTURATION IN

AMERICAN ART,

$1890-1915$

\section{Elizabeth}

\section{Hutchinson}


(C) 2009 Duke University Press

All rights reserved

Printed in the United States of America on acid-free paper $\circledast$

Designed by Heather Hensley

Typeset in Whitman by Tseng

Information Systems, Inc.

Library of Congress Cataloging-in-

Publication Data appear on the last printed page of this book. 
. . For Jane Ames Hutchinson (1938-1990) . . 
